DOI: $10.2478 /$ lpts-2014-0027

\title{
BIMODAL SPECTROSCOPY OF FORMALIN FIXED SAMPLES TO DISCRIMINATE DYSPLASTIC AND TUMOR BRAIN TISSUES
}

\author{
${ }^{1} \mathrm{~S}$. Anand, ${ }^{1,2} \mathrm{R}$. Cicchi, ${ }^{3}$ F. Giordano, ${ }^{4}$ A. M. Buccoliero, \\ ${ }^{4}$ R.Guerrini, ${ }^{1,2,5}$ F. S Pavone \\ ${ }^{1}$ European Laboratory for Non-Linear Spectroscopy (LENS), \\ University of Florence, \\ Via Nello Carrara, 1 - 50019, Sesto Fiorentino, ITALY; \\ ${ }^{2}$ National Institute of Optics, National Research Council (INO-CNR), \\ Largo Enrico Fermi 6 - 50125, Florence, ITALY; \\ ${ }^{3}$ Division of Neurosurgery, Department of Neuroscience I, \\ “Anna Meyer" Pediatric Hospital, \\ Viale Gaetano Pieraccini 24 - 50141, Florence, ITALY; \\ ${ }^{4}$ Division of Pathology, Department of Critical Care Medicine and Surgery, \\ University of Florence, \\ Viale Giovanni Battista Morgagni 85 - 50134, Florence, ITALY; \\ ${ }^{5}$ Department of Physics, \\ University of Florence, \\ Via Giovanni Sansone 1 - 50019, Sesto Fiorentino, ITALY.
}

Biomedical spectroscopy has gained attention in the past few years for disease diagnosis. Fluorescence and Raman spectroscopies provide fingerprint information related to biochemical and morphological alterations when tissues progress from the normal to a malignant stage. Usually, freshly excised tissue specimens are preferred for bio-spectroscopic studies. However, ethical issues, sample availability and distance between the surgery room and the laboratory provide an impelling restriction for in-vitro spectroscopic studies using freshly excised samples. After surgical resection tissues are fixed in $4 \%$ formalin for histological studies under a light microscope. The process of fixation prevents degradation of tissues. In this study, we probe the use of formalin fixed sample for differentiating normal and dysplastic brain tissues using fluorescence and Raman spectroscopies. It was found that fluorescence spectral profile changes in the wavelength range from $550-750 \mathrm{~nm}$ between dysplastic and tumor samples. Also, significant differences were found in the Raman spectral profiles of such samples. The results indicate a potential diagnostic application of spectroscopy in formalin fixed brain samples for differentiating dysplastic and tumor brain tissues.

Keywords: formalin fixation, fluorescence, Raman spectroscopy, brain tumor, dysplasia. 


\section{INTRODUCTION}

In the recent years, minimally invasive techniques based on optical spectroscopy and imaging have been gaining significance for tumor diagnosis and in monitoring therapeutic response of different organ sites. To such techniques we attribute the fluorescence and Raman spectroscopies. Fluorescence provides information related to the tissue metabolism and its morphological composition [1]. Raman spectroscopy - an inelastic form of scattering process - measures the characteristic spectral profiles of biomolecules related to proteins, lipids, deoxyribonucleic acid (DNA) and ribonucleic acid (RNA) [2]. Unlike fluorescence, Raman spectroscopy provides narrow-band spectral fingerprints which are exclusive to each molecule.

In the tissue optical spectroscopy, in-vivo or freshly excised tissues are preferred for measurements. But ethical issues, availability of fresh samples and sample decay - especially if the spectroscopy lab is located far away from the surgery room - remains a constraint for studies in-vivo and on freshly excised samples. Once tissues are removed, they are fixed in 4\% formaldehyde and undergo a series of steps, including slicing and staining procedure before a pathologist studies the tissue under a light microscope for analysis. The crux behind the formalin fixation is to prevent tissues from decaying by arresting autolysis and to maintain the biochemical and morphological composition of the tissue. Several studies have been reported based on the application of spectroscopic techniques to different tissue types fixed in formalin, such as oral cavity [3], breast [4], bronchus [5] and cervix [6].

In a study by Krishna et al. [3] it was found that formalin fixation of oral tissues does not affect the spectroscopic measurements; also, these authors achieved a better differentiating ability using multivariate techniques. In a similar study on the formalin fixed breast tissues, Majumder and associates achieved a sensitivity and specificity greater than 97\% [4]. Also, other studies by Gabrecht et al. [5] on bronchial tissues ruled out the possibility of using formalin fixed samples for autofluorescence imaging and spectroscopy.

Some of the investigations validate the applicability of optical spectroscopy of formalin fixed samples to better results: e.g., the case of breast tissues [4], while in some other types of tissues this concept did not work [5, 7]. Here, we present a study on the applicability of bimodal spectroscopy based on fluorescence and Raman spectroscopies in formalin fixed brain samples and assess the prediction ability between dysplasia and tumor in brain tissues.

\section{MATERIALS AND METHODS}

\section{Tissue Samples:}

For this study, a total of 16 samples including dysplastic and tumor sites were collected from Anna Meyer Pediatric Hospital, Florence, Italy. After surgical resection of suspect tumor sites the samples were fixed in $10 \%$ formaldehyde. Then they were thoroughly rinsed in phosphate buffered saline (PBS) for $\sim 5$ min before proceeding with the spectral measurements. 


\section{Instrumentation:}

The bimodal spectroscopic experimental setup, which is based on fiber optics, was used for measuring two different types of spectra: (1) fluorescence, and (2) Raman signal (Fig 1). For fluorescence spectroscopy, the setup briefly consists of two laser diodes operating at wavelengths 378 and $445 \mathrm{~nm}$ (LD-378 nm, LD-445 nm with laser diode controller TEC42, Sacher Lasertechnik GmbH, Marburg, Germany). The light from these laser diodes is made to pass through two half-wave plates (WPO-12.7CQ-0-2-355, WPO-12.7CQ-0-2-442, Lambda, Costa Mesa, California, United States), one for each of them. This changes the polarization of incident light and is also used for maximizing optical coupling. Two light beams are combined together to follow the same optical path by means of a dichroic mirror (DM- FF409Di02-25X36mm, Semrock, Rochester, New York, United States).

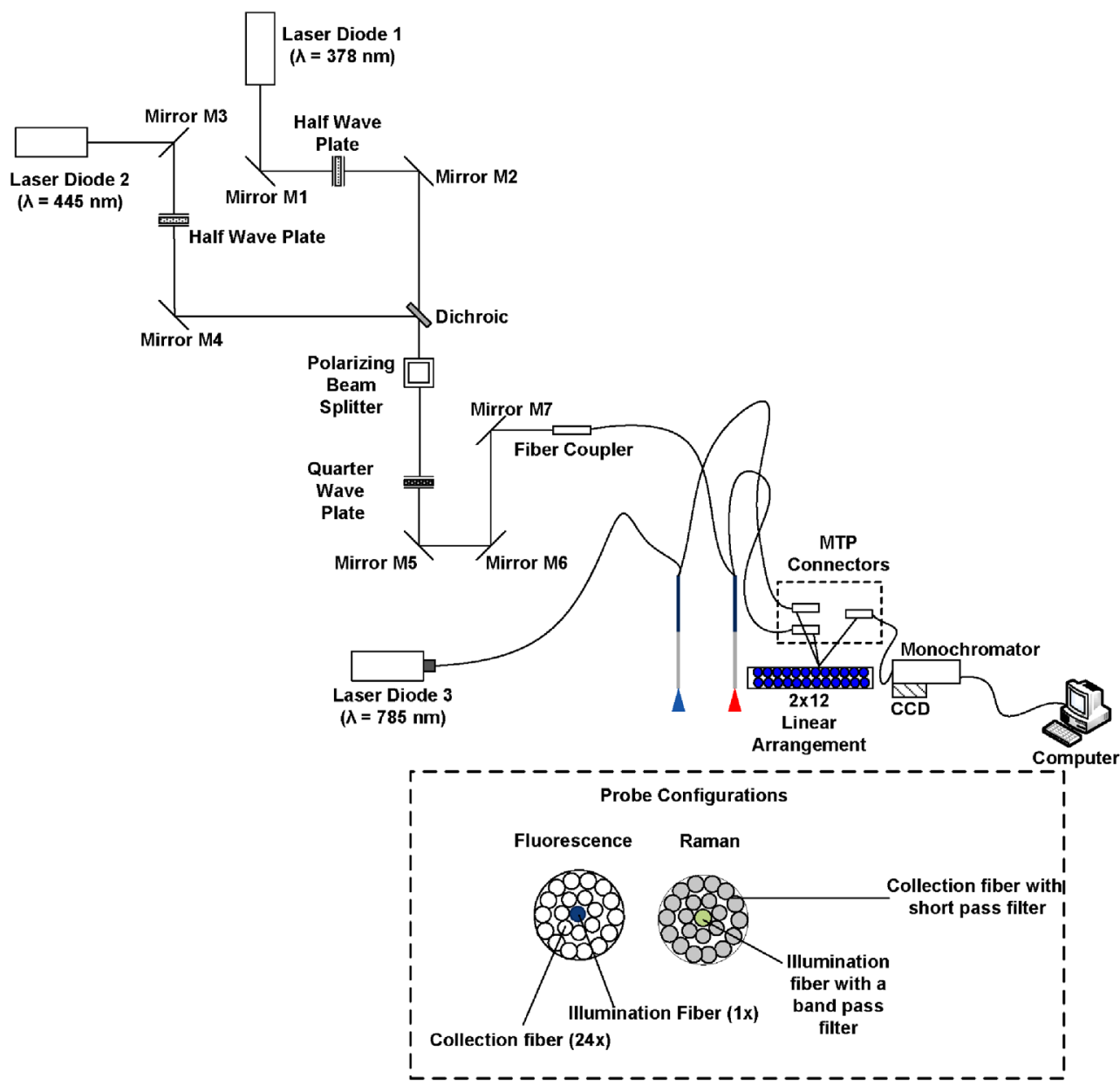

Fig. 1. Experimental schematic of the fiber optic based bimodal system incorporating fluorescence and Raman spectroscopies. Inset: the fiber optic configuration. Both probes have a single illumination fiber and 24 collection fibers. For Raman probe the illumination fiber has a bandpass filter and collection fibers with a ring shaped short-pass filter glued to the fiber tip. 
To prevent back reflections of light a polarizing cube beam splitter (PBSGTH10M, Thorlabs, Newton, New Jersey, United States) and a quarter wave plate (WPA1212-L/4-375-445, Casix, Fuzhou Fujian, China) are placed in the path of beam before it is coupled to the illumination fiber by means of a fiber coupler (ElyPrizmatix, Modiin Ilite, Israel). The fiber optic probe used for fluorescence measurements in this study consists of a central illumination fiber and 24 surrounding collection fibers (EMVision LCC, Loxahatchee, Florida,United States). The outputs of laser diodes used for fluorescence measurements are controlled via computer. For Raman spectral acquisition the light from a $785 \mathrm{~nm}$ laser diode (FC-785-350MM2-PC-0-RM, RGBLase, Fremont, California, United States) is directly coupled to central illumination fiber (EMVision LCC, Loxahatchee, Florida, United States) by means of an FC/PC connector. The fiber optic probe by itself generates fluorescence and Raman signal because of the excitation light. To suppress this stray light from illuminating tissues of interest, a narrow band pass filter is placed at the distal tip of the illumination fiber. A ring-shaped short-pass filter is placed at the end of collection fibers to prevent detection of elastically scattered light from the tissue. All the fibers used for fluorescence and Raman spectroscopy probes were of low $\mathrm{OH}$ content and had a numerical aperture (NA) of 0.22 with $100 \mu \mathrm{m}$ core diameter. The fiber optic probes had a bifurcation similar to the Y-shape, which allowed connecting the central fiber to the respective light sources and the surrounding fibers to the detector. Proximal ends of the fluorescence and Raman fiber optic probes are terminated with an MTP connector which allows sharing the same detection unit for collecting signals of interest. A custom-designed fiber bundle branch (EMVisionLCC, Loxahatchee, Florida, United States) was used to connect the optical probes and the detection system. This fiber bundle consists of 24 optical fibers (with $100 \mu \mathrm{m}$ core diameter and NA 0.22) arranged in two lines (see inset in Fig 1). Light beams from the collection fibers are connected to a monochromator (Micro HR, HORIBA Jobin Yvon, Edison, New Jersey, United States) incorporated with a filter wheel. Three different filters have been used in this study: (1) two long-pass filters (03LWP402, CVI Melles Griot, Albuquerque, New Mexico, United States and LP02-458RS-25, Semrock, Rochester, New York, United States) to measure fluorescence light at excitation wavelengths 378 and $445 \mathrm{~nm}$, respectively; (2) a notch filter (NF03-785E-25, Semrock, Rochester, United States) to prevent Rayleigh scattered light at excitation wavelength for Raman measurements. The spectroscopic signals are collected by means of thermoelectrically cooled CCD (Syncerity, HORIBA Jobin Yvon, Edison, New Jersey, United States).

\section{RESULTS AND DISCUSSION}

Figure $2 a, b$ shows the comparative emission profiles of freshly excised formalin fixed samples. Differences were observed at wavelengths greater than 510 and $570 \mathrm{~nm}$ for 378 and $445 \mathrm{~nm}$ excitation wavelengths. In the case of Raman spectrum there is a decreased intensity for formalin fixed samples when compared with fresh samples (Fig. 2c). In Fig.2d it is seen that the Raman spectra of formalin and spectral profile of tissues are not affected by formalin fixation. 
(a)

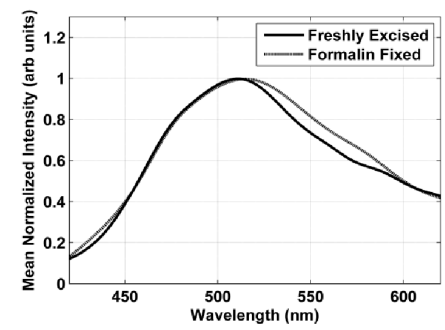

(c)

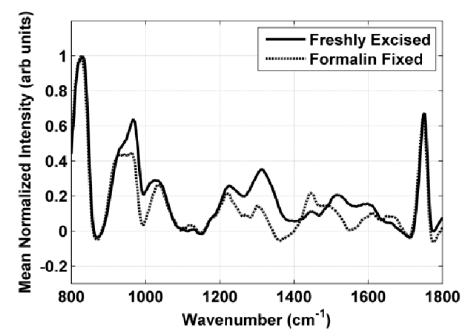

(b)

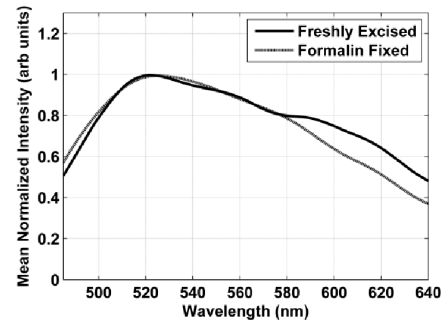

(d)

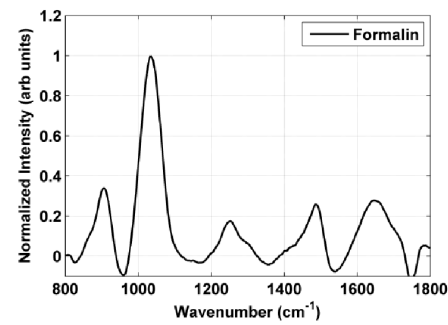

Fig. 2. Comparison of fluorescence emission spectra between freshly excised and formalin-fixed samples at excitation: (a) $378 \mathrm{~nm}$; (b) $445 \mathrm{~nm}$. Raman spectra of: (c) freshly excised and formalinfixed samples; (d) formalin.

Figure $3 a, b$ shows the emission spectral profiles for two excitation wavelengths. For fluorescence at $378 \mathrm{~nm}$, spectral differences were observed in the wavelength range above $600 \mathrm{~nm}$. Excitation at $445 \mathrm{~nm}$ shows variations in the spectral range from 550 to $680 \mathrm{~nm}$. Raman signatures for tumor and dysplastic tissues were collected in the fingerprint region $800-1800 \mathrm{~cm}^{-1}$. It is seen that Raman spectrum is dominated by tissue auto-fluorescence. The $5^{\text {th }}$ order polynomial was fit to raw spectrum and subtracted so that the Raman signal could be obtained (Fig. 3c). Figure $3 d$ represents the Raman spectral profiles of dysplastic and tumor tissues.

(a)

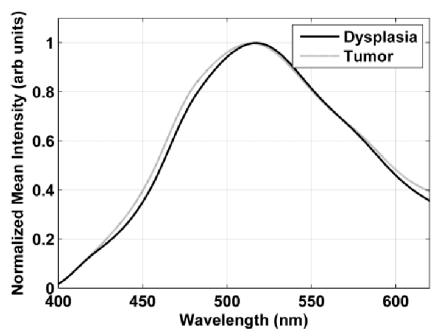

(c)

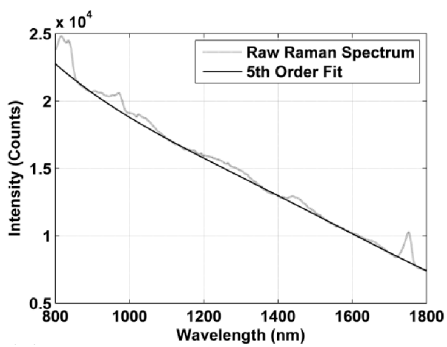

(b)

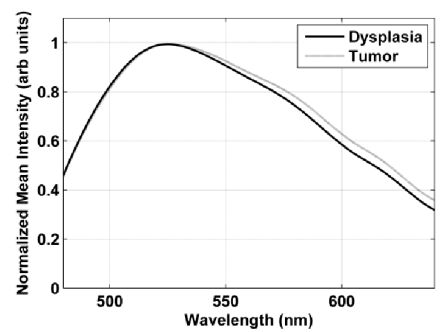

(d)

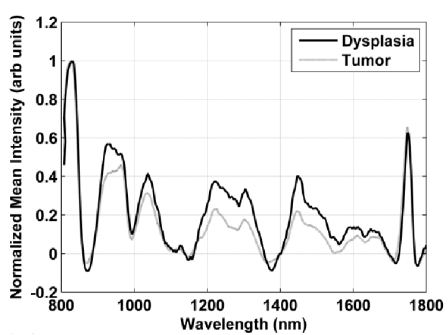

Fig. 3. Fluorescence spectral profile of normal and dysplastic tissues at (a) $378 \mathrm{~nm}$; (b) $445 \mathrm{~nm}$; (c) raw Raman spectrum with the $5^{\text {th }}$ order polynomial fit for removing the background auto-fluorescence; (d) comparative Raman spectra of dysplastic and tumour tissues. 
The principal component analysis (PCA) was used to predict the differentiation ability of spectroscopic data. This method uses an orthogonal transformation and reduces dimension of the spectral data. Also, this accounts for principal components with a greater variability. Sensitivity and specificity using this technique was found to be $77 \%$ and $78 \%$, respectively.

\section{CONCLUSIONS}

It has been found that spectroscopy of formalin fixed brain samples can effectively be used to probe the alternations in biochemical composition of tissues, thus serving as an alternate to the tissue histology. Of importance also is that the results provide a strong support to the work on larger samples in order to obtain statistically significant results.

We are continuing our efforts to make instrumentation compact and portable so that the setup could be used in an operating room to provide real time results and to give valuable support for the surgeon in assessing the tumor margin.

\section{ACKNOWLEDGEMENTS}

The authors acknowledge the funding from Fondazione Pisa in framework of the project "Diagnostic technology for the post-operative monitoring of pediatric brain tumors", European Union Seventh Framework Programme (FP7/20072013) under grant agreements number 228334 and 284464, and Italian Ministry for Education, University and Research in the framework of the Flagship Project NANOMAX. Financial support by "Ente Cassa di Risparmio di Firenze" (Private Foundation) is acknowledged.

\section{REFERENCES}

1. Ramanujam, N. (2000). Fluorescence spectroscopy of neoplastic and non-neoplastic tissues. Neoplasia, 2(1-2), 89-117.

2. Mahadevan-Jansen, A. \& Richards-Kortum, R.R. (1996). Raman spectroscopy for the detection of cancers and precancers. Journal of Biomedical Optics, 1(1), 31-70.

3. Krishna, C.M., et al. (2004). Micro-Raman spectroscopy for optical pathology of oral squamous cell carcinoma. Appl. Spectrosc., (9), 1128-35.

4. Majumder, S.K., Ghosh, N., \& Gupta, P.K. (2005). N2 laser excited autofluorescence spectroscopy of formalin-fixed human breast tissue. Journal of Photochemistry and Photobiology, B: Biology, 81(1), 33-42.

5. Gabrecht, T., Andrejevic-Blant, S., \& Wagnières, G. (2007). Blue-violet excited autofluorescence spectroscopy and imaging of normal and cancerous human bronchial tissue after formalin fixation. Photochemistry and Photobiology, 83(2), 450-459.

6. Krishna, C.M., et al. (2007). Vibrational spectroscopy studies of formalin-fixed cervix tissues. Biopolymers, 85(3), 214-21.

7. Huang, Z., et al. (2003). Effect of formalin fixation on the near-infrared Raman spectroscopy of normal and cancerous human bronchial tissues. International Journal of Oncology, 23(3), 649-55. 


\title{
FORMALĪNĀ FIKSĒTU SMADZEN̦U AUDU PARAUGU BIMODĀLĀ SPETROSKOPIJA DISPLASTISKU UN AUDZĒJA AUDU ATŠĶIRŠANAI
}

\author{
S. Anand, R. Cicchi, F. Giordano, A. M. Buccoliero, \\ R.Guerrini, F. S Pavone
}

K ops a vi $1 \mathrm{kums}$

Pēdējos gados minimāli invazīvas tehnologijas, kas balstītas uz optisko spektroskopiju un attēlošanu, ir kḷuvušas nozīmīgas audzēju diagnostikā un orgānu atbilžu reakciju monitoringā. Fluorescence un Ramana spektroskopija piedāvā informāciju par bioķīmisku un morfoloǵisku procesu izmaināām, audiem progresējot no normāliem uz l̦aundabīgiem.

Pēc ķirurğiskas audu izņemšanas tie tiek fiksēti 4\% formalīnā histoloǵiskiem pētījumiem gaismas mikroskopā. Šajā pētījumā tika iegūti fluorescences un Ramana spektri no normāliem un displastiskiem smadzeņu audiem, lai veiktu to diferencēšanu.

Rezultātā tika iegūts, ka fluorescences spektrs viļ̣na garumu diapazonā no 550$750 \mathrm{~nm}$ ir atšksirīgas audzēja un displastiskiem audiem, kā arī abu dažādo audu Ramana spektros tika novērotas būtiskas atšksirības. Šie rezultāti norāda uz potenciālu diagnostisku pielietojumu formalīnā fiksētu smadzeņu audu spektroskopijai, lai atšķirtu displastiskus un audzēja audus. 